\title{
HYPHOMYCETES FROM VARIOUS TYPE OF SOIL IN AHMEDNAGAR DISTRICT (M.S)
}

\author{
Sanjay P. Ghanwat \\ Department. of Botany, Shri Dnyaneshwar Mahavidyalay, Newasa. Dist. \\ Ahmednagar, -414603 Maharashtra, India. \\ E-mail: sanjayghanwat95@gmail.com
}

\begin{abstract}
Total twenty species of Hyphomycetes collected from the agriculture, forest and sugarcane industries effluent soil. 16 species were isolated from Agriculture soil, 19 species from forest soil and 8 species from sugarcane industries effluent agriculture soil. Sugarcane effluent used in agriculture soils every year by farmer as fertilizer seems to be suppressing the occurrence of hyphomycetes in such soils.
\end{abstract}

Keywords: Forest soil, Agricultural soil; Hypomycetes; Sugarcane industry effluent agriculture soil..

\section{INTRODUCTION:}

Hypomycetes consist the major group of soil mycoflora (Gilman 1957), Domschand Gams 1972, Domsch et.al, 1980). They are found mainly as decomposers of organic debris (Subramanian 1983), roots (Waid 1947), as soil borne pathogens (Garrett, 1979) or in association with living root in the rhizosphere zone pathogens (Garrett 1979) or in association with the wide distribution of Hypomycetes in soil is due their competitive saprophyte ability (Garrett 1956). As decomposers they help in the recycling process of Nature's cycle. The occurrence and distribution of Hypomycetes in the soil is influenced by the physical and biological factors of the soil (Subramanian, 1983).

\section{MATERIALS AND METHODS:}

Hypomycetes from various soils were isolated on the culture media by serial dilution technique (Waksman, 1931). Soil samples upto15 cms deep collected from Agriculture, Forest and Sugarcane industries effluent were brought to the laboratory in plastic bags and inoculated on PDA and Czapeks Dox Agar culture medium by serial dilution technique. The inoculated plates were incubated at $25 \pm 2^{\circ}$ $\mathrm{C}$ for the growth of fungi. After seven days the colony character were noted and a bit of colony was mounted in lacto phenol for studying microscopic characters.

\section{RESULT AND DISCUSSION:}

1) Alternaria triticina Prassad and Prabhu (1963),

Indian Phytopath. 15:292-293.

Colonies dark blackish brown to black. Conidiophores up to $344 \mu \mathrm{m}$ long. 3.3-6 $\mu \mathrm{m}$ hick in the broad less part. Conidia solitary or in short chains (2-4) rostrate, golden brown smooth, 22-95 $\mu \mathrm{m}$ long, 8-12 $\mu \mathrm{m}$ thick in the broadest part.

2) Aspergillus niger Van Tiegh (1967).

Annls.Sci.Naf. (Bot). Ser. 5, 8:240. 
Colonies effuse blackish brown conidiophore erect or flexuous often up to 3 long, 12.5-22 $\mu \mathrm{m}$ thick, upper part brown, swollen at the apex into spherical vesicle 42-68.3 $\mu \mathrm{m}$ diameter. Phialides in groups at the apices of the branches. Flask-shaped 6.3-12 $\mu \mathrm{m}$ long, 3-3.2 $\mathrm{nm}$ thick, 1-5 $\mu \mathrm{m}$ wide at the open end. Conidia catenate, dry, globose, brown, warts or spines arranged in discontinuous bands 3.3-6 $\mu \mathrm{m}$ diameter. Conidial head globose, blackish brown to black.

3) Candida albicans (Robin) Berkhout. (1923).

Deschimmelges Monilia, Oosporaen Torula Deisset. Ultrech 44.

Colonies white cream colourd, pasty, smooth, mycelium largely, submerged, hyaline, pseudohyphe and true hyphae are also observed; budding cells (blastoconidia) of varying shape, produced, along the hyphae at the points of septa, usually rounded, or short oval, seldom elongated produced as multilateral budding 2.8-10.5 $\mu \mathrm{m}$. Indian meter, Chlamydosphores round, large, thick walled and usually terminal.

4) Cephaliophora irregularis Thaxter (1903).

Bot. Gaz. 35: 158

Conidiophores clavate, up to $100-120 \mu \mathrm{m}$ long. 6.6-12 $\mu \mathrm{m}$ thick near the base; swollen conidiogenous cell 20-60 x16-33 $\mu \mathrm{m}$. Conidia variable in shape, often pyriform or turbinate, sometimes lobed, colourless to pale brown 1-2 septate, $2.2-45 \mu \mathrm{m}$ long: $12-33 \mu \mathrm{m}$ thick in the broadest part protuberant. Hilum $1.5 \times 3.3 \mu \mathrm{m}$ wide.

5) Cladosporium chlorocephalum (Fresen) Mason and Ellis (1953).

Mycol. pap. 56: 123-126.

Conidiophores, stipe dark brown to black up to $590-685 \mu \mathrm{m}$ long, 12-22 $\mu \mathrm{m}$ thick at base. 6.6-
12.6 $\mu \mathrm{m}$ thick. Immediately below heads. Spherical or oval, olive green by reflected light, brown by transmitted light 40-66 $\mu \mathrm{m}$ primary branches $8-22 \times 6.6-8 \mu \mathrm{m}$ Conidia olive or pale brown smooth of verruculose, o- proximal and intermediate ones ellipsoidal or limoniform 6$12 \mu \mathrm{m} \times 3-8 \mu \mathrm{m}$ distal or terminal ones spherical $3.3 \mu \mathrm{m}$ x6.6 $\mu \mathrm{m}$.

6) Corynespora longispora Saikia and Sarbhoy. (1980)

Ind. Phytopath. 33: 466-470.

Colonies effuse blackish brown to dark brown, velvety mycelium immersed. Pale brown and hyphae septate. Conidiophores arising singly or in group of 2.5 from the cells of Stromata of terminally or laterally onto hyphae, erect straight or flexuous, pale to mid brown 8-9 septate. 360-950 $\mu \mathrm{m}$ length 5.6-8 $\mu \mathrm{m}$ thick at the base and $3.3-4.5 \mu \mathrm{m}$ at the apex. Conidia cylindrical as sub cylindrical, very rarely obclavate cylindrical straight of curved, sub hyaline to pale brown, smooth. 8.22 septate, 4.6-6.5 $\mu \mathrm{m}$ long and 3.3-5.2 um thick wide at the truncate base.

7) Curvularia fallax Boedijn (1933).

Bull.Jrd.bot.Buitenz, III, (1) :120-134

Conidiophore's brown, thread like, unbranched, conidia acrogenous verticillate or spirally arranged 23-34 x 9-12 $\mu \mathrm{m}$.

8) Curvularia pallescens. Boedijn (1933).

Bull. Jrd. bot. Buitenz, III, (1) :120-134

Common on different substratum especially in the tropics. Conidiogenous, brown, thread like, unbranched septate. Conidia acrogenous, brown, ellipsoid, curved, three or four central cell distinctly large dark brown than terminal cells. 18-30 x 7-10 $\mu \mathrm{m}$.

9) Drechslera rostrata (Drechslera) Richardson and faster. (1968). 
Trans. Br. Mycol. Soc. 51:148.

Colonies, effuse, brownish, blackish brown, mycelium immersed, velvety, conidiophores solitary or in small groups. Straight of flexuous, brown to dark brown up to 180 to $200 \mu \mathrm{m}$ long 6 to $9 \mu \mathrm{m}$ thick. Conidia thick or straight curved, post rate obclavate, 6-18 pseudo septate, end hyaline or very pale and cut off by thick, dark septa intermediate cells golden brown. 99 to $100 \mu \mathrm{m}$ long, 19-20 $\mu \mathrm{m}$ thick, in the broadest part, hilum distinctly protuberant.

10) Grallomyces portoricensis Stevens. (1918).

Bot. Gaz. 65: 245-246.

Hyphal segments usually 45-85 x 4.6-6.6 $\mu \mathrm{m}$, attachment organ $2.0-42 \times 2.5-3 \mu \mathrm{m}$ vesicles 5-7 $\mu \mathrm{m}$, diam. Conidiophores up to $70 \mu \mathrm{m}$ long out usually about 33 x $3.3-5.2$ $\mu \mathrm{m}$. Conidia 45-65 × $3.6-6.6 \mu \mathrm{m}$ branches $19.9-45 \times 4.5-6.6 \mu \mathrm{m}$

11) Penicillium purpurogenum Stoll, (1923)

La cellule33: 235-237.

Colonies velvety, white at first, becoming yellow to pinkish shades, and finally light grey green. Conodiophores arises from aerial mycelium, up to $100 \mu \mathrm{m}-1179 \mu \mathrm{m}$ long conidial fructification consist of long divergent chains, up to $80 \mathrm{um}$ long in the stages mutuale 9.9-14.5x2-2.3 $\mu \mathrm{m}$ phialides $10-13 \times 2.2 \mu \mathrm{m}$ conidia elliptical 3-3 $\mu \mathrm{m}$ $\mathrm{x} 2-2.4 \mu \mathrm{m}$. Smooth pale green.

12) Phialophora fastigiataLagerb, Lundber \& Melin (1937).

Mycologia 29:598.

Conidiophores very variable in length, 2.5-3.3 $\mu \mathrm{m}$, thick phialides lageniform, 9-15 x 2.5-3.3 $\mu \mathrm{m}$. Conidia colourless to very pale brown 3.3 $6.5 \times 1.2-2.5 \mu \mathrm{m}$.
13) Scolecobasidium variable Barrow Busch (1962).

Can. J. Bot. 40: 83-84.

Conidiophores pale olivaceous, 5-25 x 1.5-3.3 um. Conidia Cylindrical rounded at the ends or ellipsoidal, 1-3 septate, sometimes constricted at the septa, pale olivaceous, Verruculose or finely echinulate, $7-19 \times 2.5-5 \mu \mathrm{m}$.

14) Scytalidium thermophilium (cooneu \& Emersion) Austwick. (1976).

N.Z.J. Agric. Res.

Colonies effuse; grey, to black, becoming powdery. Hyphae hyaline to brown, $2-4.5 \mu \mathrm{m}$ thick except for mid to dark brown swollen cells which are up to $12.5 \mu \mathrm{m}$, diam. conidia (arthroconidia) mid to dark brown, smooth, mostly Spherical or sub-spherical and 8-13 $\mu \mathrm{m}$, diam. But sometimes oblong or ellipsoidal 8.5$16 \times 6.5-10 \mu \mathrm{m}$.

15) Taeniolella muricata (Elliss \& Everh.) Hughes.

Can. J. Bot. 36: 817.

Colonies effuse, dark brown, conidiophores scattered rather thinly, brown, 3.6 - $6 \mu \mathrm{m}$, thick. Conidia brown verruculose, mostly 3. 22. Septate 26-110 x $6.5-9 \mu \mathrm{m}$.

16) Trichocladium asperum Harz. (1871).

Bull. Soc. Imper. Moscow. 44:125-127.

Colonies effuse, cottony, grey, conidiophores 2.5 - $3.6 \mu \mathrm{m}$ thick. Conidia mostly acrogenous predominantly 1 - Septate, clavate, obovoid or ellipsoidal narrowed to a truncate base, dark brown, coarsely verrucose 12-26.6 $\mu$ m long 8 $12.5 \mu \mathrm{m}$ thick in a broadest part.

17) Trichoderma aureoriride Rifai (1969). Maycol. Pap. 116:34.

Colonies white, mycellium with few aerial hyphae or changes from white to whitish green to dull grass green. Mycelium branched, septate colourless. 1.2-6 $\mu \mathrm{m}$ wide. Conidiophores 
flexuous, compact, main. Conidiophores slender, regularly, vertically branches 4um wide, side branches arise above the septa in groups of 2-3 in turn the side branches put forth smaller branches again length of the side branches increases with the distance away from the apex which results a in conifer like appearance. Phialides long and slende base little narrow than the middle part which project into a long conical or sub cylindrical neck, in verticals Of 2-3 or rarely single and form False verticils beneath the terminal Phialides, stand at right angles and frequently bend towards the apex $6.6-73.3 \times 2-3.3 \mu \mathrm{m}$. Conidia smooth walled obovide with distinct truncate, base 2.3$3 \times 2-3 \mu \mathrm{m}$. Produced singly on the tip of the phialides and accumulated into conidial heads.

18) Trichoderma konilangbra Samuels. Petrinis kubick (1998).

Stud: Mycol. 41:1-54.

Conidiophores profusely branched, branching regular in pairs and opposed, fertile to the tip

or sterile about 80-100 $\mu \mathrm{m}$. Septate within walled extension phialides arising singly over a distance of $25 \mu \mathrm{m}$. from - the first branch, primary branch re branch intercalary phialides present.

19) Trichurus spiralis Hesselbrina (1900)

Bot. Gaz. 29:321.

Synnamata up to 2.5-3 $\mu \mathrm{m}$ high, 8-8.5 $\mu \mathrm{m}$ thick often expanded at the head to $212 \mu \mathrm{m}$ or more. Individual threads $2.5-3 \mu \mathrm{m}$ thick, setiform apices and branches coiled or spirally twisted pale to mid brown, up to $145-150 \mu \mathrm{m}$ long, 2.5-3.3 $\mu \mathrm{m}$ thick and annellides 5-8.5 $\mu \mathrm{m}$ long thick in the broadest part. Conidia mostly 4-6 x 2.5-3.3 $\mu \mathrm{m}$.

20) Veronaea coprophila (Subram. \& Lodha) M.B.Ellis.
= Sympodina coprophila Subram. \& Lodha, 1964, Antonie van Leeuwenhock 30:317- 319 328 (1964).

Colonies effuse, dark brown, Conidiophore straight, or flexous, septate, mid to dark brown, paler towards the apex where there are a number of small, flat, scars, up to $340 \mu \mathrm{m}$ long 2.5-3.5 $\mu \mathrm{m}$ thick, Conidia straight, cylindrical, rounded at the apex, conicotruncate at the base or ellipsoidal, 1-23 septate, pale brown, smooth, 4.5-10.5 $\mu \mathrm{m} \times 3.3-6 \mu \mathrm{m}$.

\section{CONCLUSION:}

Twenty species of Hyphomycetes collected from the agriculture, forest and sugarcane industries effluent soil. 16 species were isolated from Agriculture soil, 19 species from forest soil and 8 species from sugarcane industries effluent agriculture soil. Sugarcane effluent used in agriculture soils every year by farmer as fertilizer seems to be suppressing the occurrence of Hyphomycetes in such soils. The occurrence of species like Alternaria triticina Prasad and Prabhu, Aspergillus niger Van Riegh, Candida albicans (Robin) Berkhout, Cladosporium chlorocephalum (Fresen) Mason and Ellis, Corynespora longispora Saikia and Sarbhoy, Curvularia fallax Boedijn, Penicillium purpurogenum Stoll, Trichoderma konilangbra Samuels Petrini \& Kubicek. In the soils irrigated with sugar industry effluents may have become tolerant which needs to be further investigated in detail.

Acknowledgment:

The author thankful to the Principal Dr. Kalhapure G. B., Shri Dnyaneshwar Mahavidyalaya, Newasa, Vice-Principal Prof. Ghanwat A. J. Shri Dnyaneshwar Mahavidyalaya, Newasa for providing Laboratory Facilities and also for encouragement. 


\section{REFERENCES:}

Barnet. H. L. and Hunter, B.B. Ilustrated genera or imperfect fungi. Burgess Publishing Company Minnea polis, Minnesota. (1972).

Barron, G.L. "The genera of hyphomycetes from soil." The Williams and Wilkins Co. Baltimore.1968, pp. 364.

Behera, N. and Mukherji. K. G. Seasonal variations and distribution of micro fungi in forest soils of Delhi. Folia.Geo. Bot. Et. Phyto, 1985, 20: 291-312.

Behera, N. Patil, D.P. and Basu, S. Ecological study of soil micro fungi in a tropical forest soil of Orissa. India Tropical Ecology1991, 32: (1) 136-143.

Christensen, M. Soil micro fungi of dry to mesic conifer hard wood forests in Northern Wisconsin. Ecology1969, 50: 9-27.

Domsch K. H and Gams W. Fung, in agricultural Soils. Longman, London.1972, pp. 290.

Domsch, K.H. Gams, W. and Anderson, T. H. Compendium of soil fungi. 2 vols. Academic press, London.1980, pp. 859 and 405.

Ellis, M.B. "Dematiaceous hyphomycetes." Common wealth Mycological Institute, England.1971, pp. 608.

Ellis, M. B. "More Dematiaceous hyphomycetes." CME, England.1976, pp. 507.

Garratt, S.D. "Biology of Root Infecting Fungus" University Press, Cambridge. 1956, pp. 293.

Garratt, S.D. In "The Root Soil interface” (eds. Harley J. L. and Scott Russell, R.) Academic Press, New York.1979, pp.301- 363.

Gilman, J.C. "A manual of Soil fungi" 2nd ed. The Iowa State Univ. Press. Ames, Iowa. 1957 , pp. 450.
Mohanty, R.B., Panda, T, and Pani, P.K. Seasonal variations and distribution of microfungi in tropical Forest Soils of South Orissa. J. Ind. Bot. Soc.1991, 70: 287-221.

Mohanty, R.B. and Panda, T. Ecological studies of the soil microfungiina tropical forest of south Orissa in relation to deforestation and cultivation. J. Ind. Bot.Soc.1994, 73: 213216.

Mishra, R. R. Seasonal variation in fungal flora of grasslands of Varanasi (India). Tropical Ecology.1966, 7:100- 113.

Mishra R.R. and Kanaujia, R.S. Studies on ecological aspects of soil fungi. II. Edafol. Agrobial.1973, 32: 21-39.

Nagammani A, Kunwar, I.K. and Manoharachary. C. Hand Book of soil fungi. I.K. International Pvt. Ltd., New Delhi. 2006.

Subramanian. C. V. 1971, Hyphomycetes. An accerunt of Indian species except Cercospora. Indian Council of Agricultural Research. Pub. New Delhi.

Subramanian. C. V. 1983, Hyphomycetes. Taxonomy and biology. Academic Press. London. 1983, pp.502.

Waid. J.S. In." Biology of plant litter de composition (eds. Disckson, C.H. and Pungh .G.J.F.). Academic press New York.1974, pp. 175-211.

Waksman, S. A. "Principles of soil microbiology" Williams and Wilkins, Baltimore. 1931, pp. 894. 
Table No: 01: - Hyphomycetes Isolated from various type of Soils.

\begin{tabular}{|c|c|c|c|c|}
\hline $\begin{array}{l}\text { Sr. } \\
\text { No. }\end{array}$ & Name of the Species & AS & FS & SIE \\
\hline 1. & Alternaria triticina Prasad and Prabhu & + & + & + \\
\hline 2. & Aspergillus niger Van Riegh. & + & + & + \\
\hline 3 & Candida albicans (Robin) Berkhout & + & + & + \\
\hline 4. & Cephaliophora irregularis Thaxter & + & + & - \\
\hline 5. & Cladosporium chlorocephalum (Fresen) Mason and Ellis. & + & + & + \\
\hline 6. & Corynespora longispora Saikia and Sarbhoy. & + & + & + \\
\hline 7. & Curvularia fallax Boedijn. & + & - & + \\
\hline 8. & Curvularia pallescens. Boedijn & + & + & - \\
\hline 9. & Drechslera rostrata (Drechslera) Richardson and Faster. & - & + & - \\
\hline 10. & Grallomyces portoricensis Stevens. & + & + & - \\
\hline 11. & Penicillium purpurogenum Stoll. & + & + & + \\
\hline 12. & Phialophora fastigiate (Lagerb, Lundberg \& Melin) Conant. & + & + & - \\
\hline 13 & Scolecobasidium variable Barron \&Busch. & - & + & - \\
\hline 14 & Scytalidium thermophilium (Cooney \& Emerson) Austwick. & + & + & - \\
\hline 15. & Taeniolella muricata (Ellis \& Everh.) Hughes. & + & + & - \\
\hline 16 & Trichocladium asperum Harz. & - & + & - \\
\hline 17 & Trichoderm aureoviride Rifai. & + & + & - \\
\hline 18 & Trichoderma Konilangbra Samuels Petrini \& Kubicek. & + & + & + \\
\hline 19 & Trichurus spiralis Hasselbring. & + & + & - \\
\hline 20 & Veronaea coprophila (Subram. \& Lodha) M.B. Ellis. & - & + & - \\
\hline
\end{tabular}

(AS-Agriculture Soil, FS- Forest Soil, SIE- Sugarcane industries effluent agriculture soil). 